Revista Brasileira de Farmacognosia Brazilian Journal of Pharmacognosy 21(2): 262-267, Mar./Apr. 2011

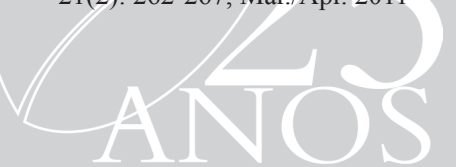

Article

Received 8 Jan 2011

Accepted 28 Jan 2011

Available online 6 May 2011

Keywords:

aquaculture

kelps

Macrocystis pyrifera

Magellan region Oncorhynchus mykiss

ISSN 0102-695X

doi: $10.1590 / \mathrm{S} 0102-695 \mathrm{X} 2011005000072$

\section{Using Macrocystis pyrifera (L.) C. Agardh from southern Chile as a source of applied biological compounds}

\author{
Andrés Mansilla, ${ }^{* 1}$ Marcela Ávila ${ }^{2}$ \\ ${ }^{1}$ Department of Sciences and Natural Resources, Universidad de Magallanes, \\ Chile, and Institute of Ecology and Biodiversity, Chile, \\ ${ }^{2}$ Institute of Science and Technology, Universidad Arturo Prat, Chile.
}

\begin{abstract}
The exploitation of seaweeds in Chile has been carried out for more than 60 years. More recently, seaweeds have been used for the production of alginate, agar and carrageenan, agricultural fertilizers and industrial aquaculture (feed for abalone and sea urchins), increasing the added value of this natural resource. In the Magellan Region $\left(56^{\circ} \mathrm{S}\right)$, the giant kelp Macrocystis pyrifera (L.) C. Agardh presents the most extensive kelp forest, reaching a biomass of approximately 12 $\mathrm{kg} . \mathrm{m}^{-2}$. Recent studies have shown potential benefits from adding M. pyriferaderived flour to salmonid feed. Research is currently underway to evaluate the use of brown algae-derived products for marine aquaculture feed of Oncorhynchus mykiss in tanks. There was no apparent adverse effect on the evaluated parameters that can be attributed to the incorporation of M. pyrifera meal in the diets fed to salmonids. Even when the control diet had numerically the best performance in zootechnical terms, the analysis of variance of all parameters evaluated showed no significant differences with regard to diets containing $M$. pyrifera meal. These results demonstrated that seaweed meal has important benefits for animal health and nutrition that could be applied or tested in other marine organisms of commercial importance.
\end{abstract}

\section{Introduction}

Some of the world's most extensive kelp forests are exclusive to the southernmost Chilean Patagonia (Magellan Strait $53-54^{\circ} \mathrm{S}$ ), which include species of Lessonia, Durvillaea antarctica and notable dominance of Macrocystis pyrifera. $M$. pyrifera is distributed along the Chilean coast from Iquique to Cape Horn (Palacios \& Mansilla, 2003; Plana et al., 2007). The populations of M. pyrifera are distributed parallel to the coast, forming continuous and irregular seaweed beds 30 to $45 \mathrm{~m}$ wide. The subtidal kelp forest grows down to $15 \mathrm{~m}$, providing habitat, refuge, food and breeding sites for other marine flora and fauna (Castilla \& Durán, 1985; Avila et al., 1982). M. pyrifera is among the largest seaweeds found in the Magellan Region, reaching a size up to $90 \mathrm{~m}$ in length.

The commercial importance of $M$. pyrifera in Chile has increased over the last decade, especially for extraction of phycocolloids such as alginates, for food additive and dietary supplement production for human consumption and animal feed, as a bio-stimulant for agricultural crops, and for the manufacture of pharmaceuticals and cosmetics, among others (Mansilla et al., 2009).

The presence of essential aminoacids and fatty acids in M. pyrifera has recently been reported and its high quality proteins and lipids are comparable to those of some terrestrial plant species (Cruz et al., 2000; Palacios \& Mansilla, 2003). It may therefore provide important dietary supplements for human consumption, for bird feed, and as a plant bio-stimulant, as well as a food supplement for the salmon farming industry (Mansilla et al., 2005). Nutritionally, algae of the genus Macrocystis provide a low-calorie low-fat food source, high in minerals ( $\mathrm{Mg}, \mathrm{Ca}, \mathrm{P}, \mathrm{K}$ and I), vitamins, protein, non-highly digestible carbohydrates, and fiber (Jiménez-Escrig \& Goñi-Cambrodon, 1999). Chemical compounds of algae vary considerably, depending on factors such as the species, geographical distribution and habitat (e.g., depth, wave exposure), season (e.g., temperature), developmental stage, influence of oceanic currents and nutrient concentrations in the environment, among others.

The aim of the present study was to evaluate the use of Macrocystis pyrifera-derived flour as a dietary supplement for intensive salmonid culturing. 


\section{Materials and Methods}

\section{Experimental design of cultures}

We used twelve tanks of $1000 \mathrm{~L}$, maintained with continuous aeration at an average water temperature of 13 to $15^{\circ} \mathrm{C}$. We placed 45 rainbow trout (Oncorhynchus mykiss) with an average individual weight of $63 \mathrm{~g}$ each per tank. The trout were maintained for five days in acclimation processes and subsequently fed ad libitum. Periodic measurements of fish weight and length were made to evaluate the daily weight and length growth rate for each treatment. The samples included $10 \%$ of the fish in each tank.

\section{Preparation of diets}

The diets were prepared in a food processing facility using extrusion processes and following procedures commonly used in the salmon industry (AOAC, 1995). Four experimental diets were used in the experiments: i. commercial feed, used as a control (D1); ii. commercial feed with $1.5 \%$ seaweed meal (D2); iii. commercial feed with $3.0 \%$ seaweed meal (D3) and iv. commercial feed with $6.0 \%$ seaweed meal (D4). Each diet was tested in three trials. We used the FORMAT software (calculation program based on linear programming) for feed formulation, considering the following general restrictions, which take into account salmonid nutritional requirements by age and species.

To evaluate the digestive use of feed, one kilogram of each of the four diet types was ground and sieved (300 $\mu \mathrm{m}$ mesh) and $1.0 \% \mathrm{Cr}_{2} \mathrm{O}_{3}$ was added as inert marker and mixed for $40 \mathrm{~min}$ in a Kitchenaid model K5SS mixer. The mixture was moistened with $30 \%$ water and pelleted in a RCA $1 \mathrm{HP}$ with a matrix of $3.5 \mathrm{~mm}$ holes. The wet pellets were oven dried for 24 $\mathrm{h}$ at $65^{\circ} \mathrm{C}$. Subsequently, the experimental diets were stored in bags and refrigerated at $-20^{\circ} \mathrm{C}$ until they were used.

\section{Seasonal nutritional profile of macroalgal flour}

Seaweed meal processed from the extraction in all four seasons (summer, autumn, winter and spring) was analyzed by proximate analysis, amino acid profile, fatty acids and minerals.

\section{Digestibility of raw materials}

To assess the digestibility of the raw material (flour of $M$. pyrifera), a modification of the method developed by Bureau et al. (1999) was employed. The digestibility of raw material of two diets consisting of $80-20 \%$ and $70-30 \%$ reference diet and seaweed meal, respectively was determined. For the preparation of each test diet, the methodology described above under Preparation of Diets was employed.

\section{Statistical treatments}

We used one-way analysis of variance (ANOVA), followed by comparisons of the means with Tukey's test (95\% confidence level). Prior to the implementation of the ANOVA, we applied the homogeneity of variance test and the arc cosine transformation, where $\mathrm{f}(\mathrm{x})=\mathrm{Cos}^{-1} \sqrt{ }(1-\mathrm{X})$ is described by Sokal \& Rohlf (1969) for percentage data. All statistical analyses were done with the Statmost 3.0 software program.

\section{Results}

\section{Seasonal nutritional profile of macroalgal flour}

The seasonal analysis of Macrocystis flour showed that the protein and ash contents are higher during spring, lipids and fibers in summer and carbohydrates in winter time (Table 1).

Table 1. Seasonal analysis of Macrocystis pyrifera flour.

\begin{tabular}{lccccc}
\hline Season & $\begin{array}{c}\text { Protein } \\
\%\end{array}$ & $\begin{array}{c}\text { Lipids } \\
\%\end{array}$ & $\begin{array}{c}\text { Carbohydrates } \\
\%\end{array}$ & $\begin{array}{c}\text { Fibers } \\
\%\end{array}$ & $\begin{array}{c}\text { Ash } \\
\%\end{array}$ \\
\hline Spring & 17.48 & 0.40 & 3.27 & 20.02 & 37.18 \\
Summer & 10.24 & 0.84 & 5.26 & 20.43 & 31.92 \\
Autumm & 9.18 & 0.61 & 6.12 & 14.58 & 35.57 \\
Winter & 11.0 & 0.47 & 8.46 & 18.94 & 29.88 \\
\hline
\end{tabular}

Chemical composition of diets

The chemical composition of the control and the experimental diets prepared with seaweed meal did not show significant differences in protein, fibers, ash or nitrogen-free compounds. Significant differences were observed in the dry matter and the ethereal extracts (Table 2).

\section{Coefficient of apparent digestibility of raw material}

Total CAD (Coefficient of Aapparent Digestibility) ranged between $85.98 \%$ (diet 4) and $86.38 \%$ (diet 1), but were not significantly different $(p>0.05)$. CAD values showed significant differences $(p<0.05)(94.20 \%$ control diet and $94.65 \%$ diet 4$)$. We found no statistically significant differences $(p>0.05)$ between the ethereal extract or the nitrogen-free extract for the CAD. Finally, the lowest CAD of energy 
Table 2. Chemical composition of the diets used in the bioassay of digestibility.

\begin{tabular}{lcccccccc}
\hline & $\begin{array}{c}\text { Diet 1 } \\
\text { Control }\end{array}$ & Sd & $\begin{array}{c}\text { Diet 2 } \\
1.5 \%\end{array}$ & sd & $\begin{array}{c}\text { Diet 3 } \\
3.0^{2}\end{array}$ & sd & $\begin{array}{c}\text { Diet 4 } \\
6.0 \%\end{array}$ & sd \\
\hline \% Dry Matter & $96.35^{\mathrm{a}}$ & 0.05 & $96.07^{\mathrm{b}}$ & 0.04 & $96.09^{\mathrm{b}}$ & 0.00 & $96.79^{\text {cd }}$ & 0.03 \\
\% Protein & $51.84^{\mathrm{a}}$ & 0.32 & $50.86^{\mathrm{a}}$ & 1.87 & $49.01^{\mathrm{a}}$ & 2.21 & $52.16^{\mathrm{a}}$ & 0.27 \\
\% Ethereal extract & $23.95^{\mathrm{a}}$ & 0.09 & $22.97^{\mathrm{b}}$ & 0.17 & $23.46^{\mathrm{a}}$ & 0.04 & $19.46^{\mathrm{c}}$ & 0.14 \\
\% E. Nitrogen-free* & $13.40^{\mathrm{a}}$ & 0.33 & $14.75^{\mathrm{a}}$ & 1.31 & $16.83^{\mathrm{a}}$ & 2.14 & $16.80^{\mathrm{a}}$ & 0.42 \\
\% Fiber & $0.77^{\mathrm{a}}$ & 0.09 & $0.89^{\mathrm{a}}$ & 0.19 & $0.80^{\mathrm{a}}$ & 0.05 & $0.98^{\mathrm{a}}$ & 0.06 \\
\% Ashes & $10.04^{\mathrm{a}}$ & 0.01 & $10.53^{\mathrm{a}}$ & 0.54 & $9.90^{\mathrm{a}}$ & 0.16 & $10.60^{\mathrm{a}}$ & 0.05 \\
$\% \mathrm{Cr}_{2} \mathrm{O}_{3}$ & 1.07 & 0.03 & 1.00 & 0.05 & 1.10 & 0.03 & 1.09 & 0.00 \\
\hline
\end{tabular}

a,b,c,d Values in the same row with different superscripts are significantly different $(p<0.05)$; The values are the average with a standard deviation (sd) $(\mathrm{n}=2$ replicates); *Nitrogen-free extract; Calculated by difference (100-Total amount of other ingredients).

Table 3. Percentage of aminoacids in the diets used in the bioassay of digestibility ( $\% \mathrm{aa} / 100 \mathrm{~g}$ diet $)$.

\begin{tabular}{lcccc}
\hline & Diet 1 & Diet 2 & Diet 3 & Diet 4 \\
& Control & $1.5 \%$ & $3.0 \%$ & $6.0 \%$ \\
\hline Asp & 3.2 & 2.3 & 1.7 & 3.3 \\
Glu & 5.7 & 4.7 & 4.6 & 5.7 \\
Ser & 3.8 & 3.7 & 1.6 & 1.5 \\
Gly & 0.8 & 1.5 & 3.5 & 2.9 \\
His & 6.4 & 6.1 & 7.0 & 5.7 \\
Arg & 3.3 & 2.3 & 3.0 & 3.1 \\
Thr & 2.1 & 2.8 & 2.3 & 1.9 \\
Ala & 3.1 & 4.8 & 2.7 & 2.7 \\
Pro & 3.1 & 4.9 & 4.2 & 2.6 \\
Tyr & 1.0 & 1.0 & 1.2 & 1.0 \\
Val & 2.5 & 3.3 & 2.9 & 2.4 \\
Met & 0.9 & 1.0 & 1.1 & 1.1 \\
Cys & 1.0 & 1.0 & 1.1 & 1.0 \\
Ileu & 2.0 & 2.2 & 2.3 & 2.0 \\
Leu & 3.4 & 3.8 & 4.0 & 3.5 \\
Phe & 2.0 & 1.6 & 2.6 & 4.6 \\
Lys & 3.2 & 3.3 & 2.6 & 3.9 \\
Met+Cys & 1.9 & 2.0 & 2.2 & 2.1 \\
Phe+Tyr & 3.0 & 2.6 & 3.7 & 5.6 \\
\hline & & & &
\end{tabular}

Table 4. Percentage of minerals in the diets used in the bioassay of digestibility.

\begin{tabular}{lcccc}
\hline & $\begin{array}{c}\text { Diet 1 } \\
\text { Control }\end{array}$ & $\begin{array}{c}\text { Diet 2 } \\
1.5 \%\end{array}$ & $\begin{array}{c}\text { Diet 3 } \\
3.0 \%\end{array}$ & $\begin{array}{c}\text { Diet 4 } \\
6.0 \%\end{array}$ \\
\hline $\mathrm{P}$ & 1.40 & 1.37 & 1.27 & 1.38 \\
$\mathrm{~K}$ & 0.63 & 0.80 & 0.80 & 0.97 \\
$\mathrm{Ca}$ & 2.00 & 1.97 & 1.83 & 1.92 \\
$\mathrm{Mg}$ & 0.14 & 0.14 & 0.13 & 0.14 \\
$\mathrm{Na}$ & 0.57 & 0.58 & 0.55 & 0.61 \\
$\mathrm{Cu}$ & 0.000983 & 0.000995 & 0.001380 & 0.0019300 \\
$\mathrm{Zn}$ & 0.0204 & 0.0217 & 0.0207 & 0.0193 \\
$\mathrm{Mn}$ & 0.0109 & 0.0121 & 0.0114 & 0.0107 \\
$\mathrm{Fe}$ & 0.0171 & 0.0212 & 0.0233 & 0.0278 \\
$\mathrm{~B}$ & 0.00113 & 0.00108 & 0.00117 & 0.00153 \\
\hline
\end{tabular}

content was observed for diet 4 (93.49\%), which was significantly lower $(p<0.05)$ than those of the other three diets (Table 5).

\section{Composition of feces}

Table 6 shows the approximate composition of feces collected during the bioassay of the digestibility of raw material. The analysis of the feces showed significant differences between dry matter and ashes

Table 5. Coefficient of apparent digestibility of the experimental diets.

\begin{tabular}{lcccccccc}
\hline & $\begin{array}{c}\text { Diet 1 } \\
\text { Control }\end{array}$ & $\mathrm{Sd}$ & $\begin{array}{c}\text { Diet 2 } \\
1.5 \%\end{array}$ & $\mathrm{sd}$ & $\begin{array}{c}\text { Diet 3 } \\
3.0 \%\end{array}$ & sd & $\begin{array}{c}\text { Diet 4 } \\
6.0 \%\end{array}$ & sd \\
\hline Total & $86.38^{\mathrm{a}}$ & 0.65 & $86.33^{\mathrm{a}}$ & 1.38 & $86.04^{\mathrm{a}}$ & 0.43 & $85.98^{\mathrm{a}}$ & 0.15 \\
Protein & $94.65^{\mathrm{a}}$ & 0.20 & $94.61^{\mathrm{a}}$ & 0.27 & $94.40 \mathrm{a}^{\mathrm{b}}$ & 0.37 & $94.20^{\mathrm{b}}$ & 0.19 \\
Ethereal extract & $99.21^{\mathrm{a}}$ & 0.12 & $99.05^{\mathrm{a}}$ & 0.19 & $99.17^{\mathrm{a}}$ & 0.15 & $99.00^{\mathrm{a}}$ & 0.03 \\
E. nitrogen-free & $72.57^{\mathrm{a}}$ & 1.39 & $73.74^{\mathrm{a}}$ & 3.12 & $74.55^{\mathrm{a}}$ & 2.08 & $74.94^{\mathrm{a}}$ & 0.18 \\
Energy & $94.32^{\mathrm{a}}$ & 0.27 & $94.08^{\mathrm{a}}$ & 0.52 & $94.21^{\mathrm{a}}$ & 0.20 & $93.49^{\mathrm{b}}$ & 0.08 \\
\hline
\end{tabular}

a,b,c,d Values in the same row with different superscripts are significantly different $(p<0.05)$. The values are the average with a standard deviation (sd) $(\mathrm{n}=2$ replicates $)$. 
Table 6. Composition of feces collected in the test of the digestibility.

\begin{tabular}{lcccccccc}
\hline & $\begin{array}{c}\text { Diet 1 } \\
\text { Control }\end{array}$ & Sd & $\begin{array}{c}\text { Diet 2 } \\
1.5 \%\end{array}$ & sd & $\begin{array}{c}\text { Diet 3 } \\
3.0^{\circ}\end{array}$ & sd & $\begin{array}{c}\text { Diet 4 } \\
6.0 \%\end{array}$ & sd \\
\hline \% Dry matter & $21.56^{\mathrm{a}}$ & 1.20 & $20.76^{\mathrm{b}}$ & 0.13 & $19.43^{\mathrm{c}}$ & 0.60 & $19.01^{\mathrm{d}}$ & 0.48 \\
\% Protein & $20.37^{\mathrm{a}}$ & 0.26 & $20.13^{\mathrm{ab}}$ & 1.03 & $19.66^{\mathrm{b}}$ & 0.98 & $21.56^{\mathrm{c}}$ & 0.53 \\
\% Ethereal extract & $1.39^{\mathrm{a}}$ & 0.16 & $1.59^{\mathrm{a}}$ & 0.22 & $1.40^{\mathrm{a}}$ & 0.29 & $1.39^{\mathrm{a}}$ & 0.05 \\
\% E. Nitrogen-free* & $26.99^{\mathrm{a}}$ & 0.41 & $28.28^{\mathrm{a}}$ & 1.06 & $30.69^{\mathrm{bc}}$ & 2.48 & $30.03^{\mathrm{c}}$ & 0.40 \\
\% Fiber & $5.11^{\mathrm{a}}$ & 0.25 & $5.74^{\mathrm{b}}$ & 0.05 & $6.26^{\mathrm{c}}$ & 0.09 & $6.10^{\mathrm{cd}}$ & 0.59 \\
\% Ashes & $46.14^{\mathrm{a}}$ & 0.10 & $44.26^{\mathrm{b}}$ & 1.10 & $41.99^{\mathrm{c}}$ & 1.27 & $40.92^{\mathrm{d}}$ & 0.14 \\
$\% \mathrm{Cr}_{2} \mathrm{O}_{3}$ & 7.52 & 0.38 & 7.64 & 0.71 & 7.63 & 0.24 & 7.85 & 0.09 \\
\hline
\end{tabular}

a,b,c,d Values in the same row with different superscripts are significantly different $(p<0.05)$. The values are the average with a standard deviation (sd) ( $\mathrm{n}=2$ replicates); *Nitrogen-free extract; Calculated by difference (100 - Total amount of other ingredients).

between all of the diets (Table 6). The percentage of protein was significantly higher in diet 4 than in diet 2 (Table 6). There were no significant differences in the ethereal extract between the diets. The lowest values of the nitrogen-free extract and of fiber in the feces were in the control diet, with $27 \%$ and $5.11 \%$, respectively; on the contrary, diet 3 had the highest proportions of these, with $30.68 \%$ and $6.26 \%$, respectively.

\section{Digestibility of minerals}

Overall, no significant differences were observed in the digestibility of minerals at the level of inclusion of the algae in the diets. There were no significant differences $(p>0.05)$ for magnesium, sodium, copper, zinc and manganese between the diets. Phosphorous content also showed no significant differences between diets 1 and 4 (Table 6).

Diet 4 potassium content was significantly $(p<0.05)$ higher than that in the other three diets. Diet 3 had the lowest value of the CAD for Calcium (13.23\%). There were differences in the CAD $(p<0.05)$ between diets 1 and 4 for boron content, but not between diet 1 and the control.

There were minor variations in the mineral content between the diets (Table 7) and small differences in the aminoacid contents (aspartic acid, serine, glycine, phenylalanine, proline, and alanine content; Table 8). No statistical comparisons were possible since only a single application of the treatment was performed.

\section{Survival}

The survival rate showed that the treatments have an influence during the first 34 days of culture, in which diet 3 showed the greatest effects with $88 \%$ survival, followed by diets 2 and 3 with $96 \%$ survival. Over the next 68 days, all treatments were stable, continuing to fall slightly to 103 days. For the entire 124 day experimental period, the the control treatment finished with better overall survival (94\%) followed
Table 7. Percentage of minerals in feces collected in the bioassay of digestibility.

\begin{tabular}{lcccc}
\hline & Diet 1 & Diet 2 & Diet 3 & Diet 4 \\
& Control & $1.5 \%$ & $3.0 \%$ & $6.0 \%$ \\
\hline $\mathrm{P}$ & 4.92 & 4.82 & 4.35 & 4.17 \\
$\mathrm{~K}$ & 0.02 & 0.02 & 0.02 & 0.02 \\
$\mathrm{Ca}$ & 11.03 & 11.63 & 11.37 & 10.70 \\
$\mathrm{Mg}$ & 0.33 & 0.32 & 0.29 & 0.31 \\
$\mathrm{Na}$ & 2.52 & 2.52 & 2.15 & 2.11 \\
$\mathrm{Cu}$ & 0.00287 & 0.00275 & 0.00295 & 0.00334 \\
$\mathrm{Zn}$ & 0.0948 & 0.1019 & 0.0959 & 0.0862 \\
$\mathrm{Mn}$ & 0.0653 & 0.0698 & 0.0662 & 0.0581 \\
$\mathrm{Fe}$ & 0.0653 & 0.0698 & 0.0662 & 0.0581 \\
$\mathrm{~B}$ & 0.00411 & 0.00452 & 0.00405 & 0.00473 \\
\hline
\end{tabular}

Table 8. Percentage of aminoacids in feces collected in the bioassay of digestibility ( $\%$ aa $/ 100 \mathrm{~g}$ feces).

\begin{tabular}{lcccc}
\hline & Diet 1 & Diet 2 & Diet 3 & Diet 4 \\
& Control & $1.5 \%$ & $3.0 \%$ & $6.0 \%$ \\
\hline Asp & 0.6 & 0.3 & 1.3 & 0.5 \\
Glu & 1.1 & 0.6 & 0.9 & 1.2 \\
Ser & 1.4 & 1.1 & 1.4 & 1.7 \\
Gly & 0.4 & 0.2 & 0.2 & 0.3 \\
His & 2.9 & 2.2 & 2.8 & 3.3 \\
Arg & 0.8 & 0.7 & 0.7 & 0.6 \\
Thr & 1.4 & 0.8 & 1.0 & 1.0 \\
Ala & 2.9 & 1.1 & 1.4 & 1.5 \\
Pro & 3.5 & 1.6 & 1.8 & 1.7 \\
Tyr & 0.6 & 0.7 & 0.6 & 0.5 \\
Val & 1.7 & 1.1 & 1.4 & 1.7 \\
Met & 1.7 & 0.9 & 0.1 & 0.6 \\
Cys & 0.4 & 0.5 & 0.7 & 0.7 \\
Ileu & 0.7 & 0.9 & 1.0 & 1.2 \\
Leu & 1.1 & 1.5 & 1.7 & 2.1 \\
Phe & 0.7 & 1.0 & 0.9 & 1.4 \\
Lys & 1.1 & 1.3 & 1.4 & 1.4 \\
Met+Cys & 2.2 & 1.5 & 0.8 & 1.4 \\
Phe+Tyr & 1.3 & 1.6 & 1.5 & 1.8 \\
\hline & & & & \\
\hline
\end{tabular}


by diet $4(90 \%)$ and diet $2(89 \%)$ and finally diet 3 $(85 \%)$. Although the best overall survival was obtained with the control diet, it should be noted that, from day 38 to 124 , diet 3 showed the highest survival rate. The analysis of variance indicated that there were no significant differences between the treatments ( $p=0.405)$ or between the means.

In the work of Bureau et al. (2003), a survival of $98 \%$ was obtained, while in this work survival between 85 and $94 \%$ was achieved, in particular $90 \%$ for diet 4 with $6 \%$ algae. The two variables, individual weight and survival, are the important ones in terms of net biomass gain.

\section{Total biomass growth}

The increase in total biomass obtained in the first 68 days with each diet showed no major noticeable differences, although the biomass of the control diet was slightly higher at the end of the experiment, finishing with $14.9 \mathrm{~kg}$. For the period from 103 to 124 days, the total biomasses were in the descending order diet 1 , diet 4 and diet 3 with values of 13.63, 13.49 and $12.75 \mathrm{~kg}$, respectively. No significant differences were found in the analysis of variance $(p=0.322)$ or the Tukey test for means.

There were no apparent adverse effects on the evaluated parameters that could be attributed to the incorporation of Macrocystis pyrifera meal into the diets administered to salmonids. Even though the control diet had the best zootechnical performance in numerical terms, the analysis of variance of all the parameters evaluated showed that there were no statistically significant differences relative to the diets containing $M$. pyrifera meal.

\section{Digestibility}

The incorporation of $1.5,3.0$, or $6.0 \%$ of algal meal into the diet did not affect the total digestibility, the digestibility of lipids or carbohydrate digestibility. However, the diet with $6 \%$ algal meal decreased the digestibility of protein and energy.

There was no evidence that the digestibility of minerals is affected by the incorporation of algae into the diets. However, there was a tendency to increase the digestibility of phosphorus in the diet with an addition of $6 \%$ algae. Although not conclusive, this effect appears to be interesting from the environmental point of view.

In contrast, high levels of inclusion (20 and $30 \%$ ) of $M$. pyrifera algal meal produce decreases in the coefficients of total digestibility of protein, lipids, and energy; however, there was no decrease in the coefficient of apparent digestibility (CAD) of the nitrogen-free extract.

As a raw material, the digestibility of algae meal is low, demonstrating that this ingredient can only be used in small amounts in the diet of fish grown commercially.

\section{Conclusions}

The incorporation of seaweed meal, at the level employed in the three experimental diets, did not affect the total digestibility of lipids or carbohydrates. The digestibility of minerals was apparently not affected. However, there was a tendency to increase the digestibility of phosphorus in diet 4 (addition of $6 \%$ seaweed meal), an important result in the context of environmental sustainability. The digestibility of algal meal as a raw material is low, demonstrating that this ingredient should only be used in small amounts in fish diets in commercial fish farms. The greatest nutritional value of seaweed meal is represented by the nitrogenfree extract and the ashes, proteins and lipids being very low in the meal. Consequently, seaweed meal cannot be considered as a real substitute for proteins or lipids, but rather as a supplement for minerals and carbohydrates. The inclusion of seaweed meal does not qualitatively or quantitatively improve the level of protein or lipids in the diet, given the profile of proteins, lipids, fatty acids and aminoacids; however, the contribution of minerals is significant with $6 \%$ inclusion of seaweed meal in the diet. The effect of inclusion of seaweed meal in the diets on the $\omega 3 / \omega 6$ ratio is almost negligible, but the percentage of polyunsaturated fatty acids in the muscle (mainly EPA, DHA and linoleic acid) increased when the level of inclusion was 3 or $6 \%$. The health of the fish during the experiment was optimal. Histopathological examination of various fish organs fed with diets of algae showed no morphological or functional alterations that would compromise their homeostatic response

These results demonstrate that seaweed meal has important benefits for animal health and nutrition that could be applied or tested in other marine organisms of commercial importance.

\section{Acknowledgment}

The authors thank the support of PFB-23 (Basal-CONICYT), P05-002 (ICM-MIDEPLAN), Project DO1I1164 Fondef - Conicyt. The technical assistance of Aliro Borquez in the bioassays is greatly appreciated. S. Murcia, C. Anderson and E. Velasquez collaborated in the translation and revision of the manuscript in English. 


\section{References}

Association of Oficial Analytical Chemists 1995. Official Methods of Analysis of the Association of Analytical Chemist. Washington, AOAC International.

Avila M, Alveal K, Romo H 1982. Comunidades de algas epifitas de Macrocystis pyrifera de Isla Navarino, Chile. Gayana Botánica 38: 3-16.

Bureau DP, Harris AM, Cho CY 1999. Apparent digestibility of rendered animal protein ingredients for rainbow trout (Oncorhynchus mykiss). Aquaculture 180: 345358.

Bureau D, Gunther PS, Cho CY 2003. Chemical composition and preliminary theoretical estimates ofwaste outputs of rainbow trout reared on commercial cage culture operations in Ontario. N Am J Aquacult 65: 33-38.

Castilla JC, Durán LR 1985. Human exclusion from the rocky intertidal zone of Central Chile: The effects on Concholepas concholepas (Gastropoda). Oikos 45: 391-399.

Cruz-Suárez LE, Rique-Marie D, Tapia-Salazar M, GuajardoCB 2000. Uso de harina de Kelp (Macrocystis pyrifera) en alimentos para camarón. Avances en Nutrición Acuícola V. In Cruz Suarez LE, RicqueMarie D, Tapia-Salazar M, Olevera_Nova MA, Civera-Cerecedo R (eds.) Memorias del V Simposium Internacional de Nutrición Acuícola, Mérida, Yucatán. p. 19-22.

Jimenez-Escrig A, Goni Cambrodon I 1999. Nutritional evaluation and physiological effects of edible seaweeds. Arch Latinoam Nutr 49: 114-120.

Mansilla A, Palacios M, Navarro N, Riquelme V 2005.
Studies of the populations of Macrocystis pyrifera (L) C. Agardh in Tierra del Fuego, Chile. Rep Polar Mar Res 507: 160-162.

Mansilla A, Ávila M, Caceres J, Palacios M, Navarro N, Cañete I Oyarzún S, 2009. Diagnóstico Bases Biológicas Explotación Sustentable Macrocystis pyrifera, (Huiro), XII Región Código BIP $\mathrm{N}^{\circ}$ 30060262-0. Gobierno Regional de Magallanes y Antártica Chilena. Informe de Proyecto, Universidad de Magallanes, Chile. 345pp.

Palacios M, Mansilla A 2003. Desarrollo de gametofitos y esporofitos de Macrocystis pyrifera (L.) C. Agardh (Laminariales: Lessoniaceae) de la Región de Magallanes en condiciones de laboratorio. Anales del Instituto de la Patagonia Cs Nat 31: 43-63.

Plana J, Mansilla A, Palacios. M, Navarro N 2007. Estudio poblacional de Macrocystis pyrifera (1.) C. Agardh (Laminariales: Phaeophyta) en ambientes protegido y expuesto al oleaje en tierra del fuego. Gayana 71 : 66-75.

Sokal RR, Rohlf FJ 1969. Biometry. New York: W.H. Freeman and Company, p. 327-332.

\section{*Correspondence}

Andrés Mansilla

Department of Sciences and Natural Resources, Universidad de Magallanes P.O. Box 113-D Punta Arenas, Chile

Institute of Ecology and Biodiversity

P.O. Box 653 Santiago, Chile

andres.mansilla@umag.cl

Tel.: +56 61207089

Fax: +5661212835 